\title{
Induction of vasculogenesis in breast cancer models
}

\author{
K Shirakawa ${ }^{1,3}$, S Furuhata', I Watanabe', H Hayase ${ }^{3}$, A Shimizu', Y Ikarashi', T Yoshida' ${ }^{2}$ M Terada², \\ D Hashimoto ${ }^{3}$ and $\mathbf{H}$ Wakasugi*,
}

'Pharmacology Division, National Cancer Center Research Institute, Tsukiji 5-I-I, Chuo-Ku, Tokyo 104-0045, Japan; ${ }^{2}$ Genetics Division, National Cancer Center Research Institute, Tsukiji 5-I-I, Chuo-Ku, Tokyo 104-0045, Japan; ${ }^{3}$ Department of Surgery, SaitamaMedical Center, SaitamaMedical School, 981

Tsujido-machi, Kamoda, Kawagoe-shi, Saitama 350-8550, Japan

Recently, there have been reports of postnatal vasculogenesis in cases of ischaemia models. The aim of the present study is to provide evidence of postnatal vasculogenesis in breast-cancer-bearing mice. Based on cell surface antigen expression, we isolated endothelial precursor cells from bone marrow, peripheral blood and tumour-infiltrating cells from mice that had received six human breast cancer xenografts. In all three areas (bone marrow, peripheral blood and tumour-infiltrating cells), endothelial precursor cell population was elevated in all transplanted mice. Differentiation and migration activities of endothelial precursor cells were measured by comparing levels of the endothelial precursor cell maturation markers Flk-I, FltI, Tie2, VE-cadherin and CD3I among these three areas. The endothelial precursor cell population was 14\% or greater in the gated lymphocyte-size fraction of the inflammatory breast cancer xenograft named WIBC-9, which exhibits a hypervascular structure and de novo formation of vascular channels, namely vasculogenic mimicry (Shirakawa et al, 200 I). In vitro, bone marrow-derived endothelial precursor cells from four human breast cancer xenografts proliferated and formed multiple clusters of spindle-shaped attaching cells on a vitronectin-coated dish. The attaching cells, which incorporated Dil-labelled acetylated low-density lipoprotein (Dil-acLDL) and were negative for Mac-I. The putative bone marrow derived endothelial precursor cell subset, which was double positive of CD34 and Flk-I, and comparative bone marrow derived CD34 positive with Flk-I negative subset were cultured. The former subset incorporated Dil-acLDL and were integrated with HUVECs. Furthermore, they demonstrated significantly higher levels of murine vascular endothelial growth factor and interleukin-8 in culture supernatant on time course by enzyme-linked immunosorbent assay. These findings constitute direct evidence that breast cancer induces postnatal vasculogenesis in vivo.

British Journal of Cancer (2002) 87, |454-|46|. doi:I0.1038/sj.bjc.66006I0 www.bjcancer.com

(C) 2002 Cancer Research UK

Keywords: endothelial cells (ECs); endothelial precursor cells (EPCs); breast cancer; angiogenesis; vasculogenesis

Postnatal neovascularisation is thought to result exclusively from proliferation and remodelling of fully differentiated ECs derived from pre-existing blood vessels (Holash et al, 1999). This adult paradigm, referred to as angiogenesis, contrasts with vasculogenesis, the term applied to the formation of embryonic blood vessels from endothelial precursor cells (EPCs). Recently, however, EPCs have been isolated from adult peripheral blood (PB) and umbilical cord blood, and these cells attach themselves to vitronectin-coated dishes (Asahara et al, 1997; 1999; Isner and Asahara, 1999; Takahashi et al, 1999; Kalka et al, 2000; Murohara et al, 2000). Augmentation of transfused EPCs has been observed in ischaemic tissue, and participation of transfused EPCs in neovascular formation has been observed in mature animal models. Previously, we reported the establishment of a new human IBC xenograft (WIBC-9) that exhibits angiogenesis and de novo formation of vascular channels, vasculogenic mimicry (Shirakawa et al, 2001). WIBC-9 overexpresses human (h) angiogenic factors (interleukin-8 (IL-8), vascular endothelial growth factor (VEGF), basic fibroblast growth factor (bFGF), angiopoietin-1 (Ang-1)) and murine (m) angiogenic factors (integrin $\alpha \mathrm{v} \beta 3$, flt-1, tie-2, VEGF, Ang 2), compared with 3 non-IBC xeno-

*Correspondence: H Wakasugi; E-mail: hwakasug@gan2.ncc.go.jp Received 4 April 2002; revised 22 August 2002; accepted 29 August 2002 grafts, at the mRNA and/or protein level. Previously, by blocking the VEGF-Flt-1 and Angiopoietin 1,2-Tie2 pathways in IBC, we achieved a ratio of tumour growth inhibition of $99 \%$ or greater and demonstrated marked anti-angiogenic and putative antivasculogenic effects (Shirakawa et al, 2002). In the present study, we tested our hypothesis that human breast cancer lines (specifically, WIBC-9) can induce proliferation, of ECs and EPCs in animal models.

\section{MATERIALS AND METHODS}

\section{Human VEGF transfection vector (pcDNA3-hVEGF) and cell lines}

An EcoRI-HindIII $0.6 \mathrm{~kb}$ human(h)VEGF cDNA fragment was subcloned into the pcDNA3.1/Neo vector (Invitrogen, San Diego, CA, USA). SK-BR3 and MCF-7 cells (American Type Culture Collection, Rockville, MD, USA) grown in DMEM with $10 \%$ FBS were transfected with this expression construct (pcDNA3.1/hVEGF) or with the vector alone (pcDNA3.1/Neo) using the Lipofectamine Plus reagent (Invitrogen, San Diego, CA, USA) and selected with Geneticin(G418) (Invitrogen, San Diego, CA, USA). Stably-transfected SK-BR3/hVEGF and MCF7/hVEGF cell lines were maintained in media containing $400 \mu \mathrm{g} \mathrm{ml}^{-1}$ Geneticin. 


\section{Xenografts}

WIBC-9 and the established non-IBC xenografts MC-2, MC-5 and MC-18 were maintained as described elsewhere (Shirakawa et al, 2001). SK-BR3, MCF-7, SK-BR3/hVEGF and MCF-7/ hVEGF cells were injected subcutaneously into the second mammary fat pads of athymic, female, ovariectomised 4-weekold BALBc nu/nu mice $\left(10^{7}\right.$ cells $100 \mu \mathrm{l}^{-1}$ serum-free culture medium). To evaluate EPCs and hVEGF concentration in peripheral blood, retro-orbital bleeding into capillary tubes was undertaken from tumour-bearing mice $(n=5$ per study group) when the tumour became $10 \mathrm{~mm}$ in maximum diameter after transplant. Femurs were also undertaken from these mice to extract bone marrow. All animal experiments have been carried out with ethical committee approval. The ethical guidelines that were followed meet the standards required by UKCCCR guidelines (Workman et al, 1998). WIBC-9 and the established non-IBC xenografts MC-2, MC-5 and $\mathrm{MC}-18$ were maintained as described elsewhere (Shirakawa et al, 2001).

The animals received a weekly percutaneous administration of $100 \mu \mathrm{g}$ of $17 \beta$ estradiol (Sigma, Saint Louis, MO, USA) in $10 \mu \mathrm{l}$ of ethanol, in order to obtain tumours with a volume of $1000 \mathrm{~mm}^{3}$.

\section{Mobilisation of ECs and EPCs by recombinant human GM - CSF (rhGM - CSF) and rhVEGF}

rhGM-CSF (molecular weight, $14 \mathrm{kD}$ ) and rhVEGF (molecular weight, $38.2 \mathrm{kD}$ ), in powdered form (Sigma), were dissolved in phosphate-buffered saline (PBS). To determine the mobilisation activity of GM - CSF and VEGF on ECs and EPCs, $50 \mathrm{ng}$ of rhGM - CSF or $10 \mathrm{ng}$ of rhVEGF was injected into BALB/c nude mice (Clea Japan, Tokyo, Japan) intraperitoneally as in vivo controls.

\section{Preparation of cultured conditioned medium and determination of hVEGF concentration by ELISA}

SK-BR3, SK-BR3/hVEGF, MCF-7 and MCF-7/hVEGF cells $\left(1 \times 10^{6}\right.$ cells well $\left.{ }^{-1}\right)$ were incubated for 2 days at $37^{\circ} \mathrm{C}$, and the supernatants were then collected and stored at $-80^{\circ} \mathrm{C}$ until used. Concentration of hVEGF was measured by ELISA in $100 \mu \mathrm{l}$ samples of supernatant, using immunoassay kits (Immuno-Biological Laboratories Co., Ltd., Fujioka, Japan). Each assay was performed in triplicate.

\section{Flow cytometry (quantitation of EPCs and ECs)}

To examine quantity and differentiation of EPCs, mononucear cells (MNCs) (derived from BM, PB and TI cells) from each xenografted $\mathrm{BALB} / \mathrm{c}$ nude mouse $(n=5)$ were subjected to flow cytometric analysis to examine surface expression of the proteins mFlk-1, mFlt-1, mTie2, mVE-cadherin, mCD31, mCD34, mCD45, mTER (an erythroid marker) and mMac-1 (CD11b; myeloid marker). Resected xenografts were passed three times through a $200 \mu \mathrm{m}_{\text {gauge }}{ }^{-1}$ stainless steel mesh after being minced. The cells were suspended in a medium containing a $20-60 \%$ Percoll $^{\mathrm{TM}}$ gradient (Amersham Pharmacia Biotech, Uppsala, Sweden) and centrifuged at 1500 r.p.m. for $20 \mathrm{~min}$ at room temperature. The cells in the 30\% layer of Percoll were then collected, and erythrocytes were removed by treatment with $0.83 \%$ ammonium chloride in $10 \mathrm{~mm}$ Tris- $\mathrm{HCl}$ ( $\mathrm{pH} 7.5$ ). Peripheral blood was centrifuged on lymphosepar 2 (ImmunoBiological Laboratories, Gunma, Japan) at 1800 r.p.m. for $30 \mathrm{~min}$ at room temparature after red cell lysis and the cells were collected as MNCs. Bone marrow from the femur was also treated with $0.83 \%$ ammonium chloride in $10 \mathrm{~mm}$ Tris- $\mathrm{HCl}(\mathrm{pH} 7.5)$ for red cell lysis and subjected to flow cytometric analysis. Rat anti-murine (m) CD31, biotin-conjugated rat anti-mCD34, rat anti-mCD45, rabbit anti-mFlt-1, phycoerythrin(PE)-conjugated rat anti-mFlk-1, rabbit anti-mTie-2, goat anti-mVE-cadherin, rat anti-mTER119, and rat anti-mMac-1 (BD Pharmingen, San Diego, CA, USA) were used as the primary antibodies. Anti-rat fluorescein isothiocyanate (FITC), anti-rabbit FITC, anti-goat FITC and anti-rat-phycoerythrin (PE), streptavidin-peridinin chlorophyll-a Protein(PerCP) (BD Pharmingen, San Diego, CA, USA) were used as the secondary antibodies. All primary antibodies were subjected to isotype control. To analyse the EPC or EC population, we gated on the lymphocyte-size fraction (Murohara et al, 2000). EPCs(mCD34+, mFlk-1+) in the BM,PB and TI were enumerated by three-colour flow cytometry to detect the expression of mFlt-1, mTie-2, mVE-cadherin, mCD31.

\section{EPC culture}

On day 1 of culture, BM- or PB-derived EPCs were cultured in Stem pro (GIBCO BRL, Grand Island, NY, USA). Floating MNCs and sorted mCD34-positive MNCs were cultured overnight on non-coated plastic plates, and $5 \times 10^{5}$ cells were then transferred to murine fibronectin-coated plastic plates (GIBCO BRL) for culturing. From day 2 of culture, EPCs were cultured in SFM (GIBCO BRL) supplemented with $20 \%$ FBS and bovine pituitary extract. On days 4 and 13 of culture, AT cells and clusters were

Table I EPC population in human breast cancer xenografts and chemotactic effect

\begin{tabular}{|c|c|c|c|c|c|c|c|}
\hline & \multicolumn{2}{|c|}{ BM } & \multicolumn{3}{|c|}{ PBC } & \multicolumn{2}{|c|}{ TI } \\
\hline & $\begin{array}{c}\text { CD34 }^{+}+\text {Flk- }^{+} \\
\text {(\%) }\end{array}$ & $\begin{array}{c}\mathrm{CD}^{2} 4^{+}+\mathrm{CD}^{-} 5^{-} \\
+\mathrm{TER}^{-}+\mathrm{Mac}^{-} \mathrm{I}^{-} \\
(\%)\end{array}$ & $\begin{array}{c}\text { MNCs } \\
\left(\times 10^{4} \text { cells } \mathrm{ml}^{-1}\right)\end{array}$ & $\begin{array}{c}\text { CD34 }^{+}+\text {Flk- }^{+} \\
\left(\times 10^{4} \text { cells } \mathrm{ml}^{-1}\right)\end{array}$ & 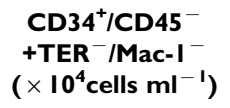 & $\begin{array}{c}\text { CD34 }^{+}+\text {Flk- }^{+} \\
(\%)\end{array}$ & $\begin{array}{c}\mathrm{CD}^{+} 4^{+} / \mathrm{CD}^{-} 5^{-} \\
\text {+TER }^{-} / \mathrm{Mac}^{-\mathrm{I}^{-}} \\
(\%)\end{array}$ \\
\hline Control & $0.1 \pm 0.1$ & $0.1 \pm 0.1$ & $112 \pm 15$ & $1.1 \pm 0.9$ & $1.0 \pm 0.8$ & - & - \\
\hline WIBC-9 & $14.3 \pm 3.2 * *$ & $10.6 \pm 2.1 * * *$ & $302 \pm 24 * *$ & $39.6 \pm 6.9$ *** & $21.6 \pm 6.3^{* * *}$ & $28.1 \pm 6.1^{*}$ & $14.2 \pm 2.7^{* * *}$ \\
\hline MC-2 & $0.5 \pm 0.2 *$ & $0.4 \pm 0.1 *$ & $130 \pm 13$ & $9.1 \pm 2.6^{*}$ & $1.6 \pm 0.5$ & $1.4 \pm 0.2$ & $0.5 \pm 0.1$ \\
\hline MC-5 & $1.8 \pm 0.4 *$ & $0.8 \pm 0.2 *$ & $149 \pm 18 *$ & $2.3 \pm 0.6^{*}$ & $2.6 \pm 0.6 *$ & $2.7 \pm 0.3$ & $1.5 \pm 0.2$ \\
\hline$M C-18$ & $2.8 \pm 1.0 *$ & $3.5 \pm 1.0 *$ & $119 \pm 36$ & $2.7 \pm 1.0 *$ & $3.5 \pm 1.0 *$ & $7.5 \pm 2.1$ & $3.5 \pm 1.1$ \\
\hline MCF-7 & $2.8 \pm 0.5^{*}$ & $1.3 \pm 0.3 *$ & $122 \pm 21$ & $2.6 \pm 0.7$ * & $3.0 \pm 1.1^{*}$ & $2.7 \pm 0.3$ & $1.5 \pm 0.2$ \\
\hline MCF7/hVEGF & $9.8 \pm 3.3^{* * *}$ & $7.3 \pm 1.6 * *$ & $270 \pm 46 * * *$ & $22.9 \pm 7.0$ **** & $20.5 \pm 6.2^{2 * * *}$ & $16.3 \pm 3.6 *$ & $10.2 \pm 2.8^{*}$ \\
\hline rhGM-CSF (50 ng × 4 i.p.) & $0.5 \pm 0.1 *$ & $0.6 \pm 0.1 *$ & $200 \pm 39 * *$ & $7.6 \pm 1.2 * * *$ & $11.8 \pm 1.6 * * *$ & & \\
\hline rhVEGF ( $10 \mathrm{ng} \times 4$ i.p.) & $0.7 \pm 0.2 *$ & $0.8 \pm 0.2 *$ & $120 \pm 11$ & $5.8 \pm 1.5 * * *$ & $7.4 \pm 2.5^{*} *$ & & \\
\hline
\end{tabular}

EPC population in human breast cancer xenografts. MNCs derived from BM, PB and TI cells in each human breast cancer xenografted BALB/C nude mice: WIBC-9, MC-2, MC-5, MC-18, MCF-7, MCF-7/huVEGF and control ( $n=5)$ were subjected to flow cytometric analysis to examine surface expression of Flk-I, CD34, CD45, TER, and Mac-I. Each xenografted tumour was adjusted to $10 \mathrm{~mm}$ in diameter. In BM, PB and TI cells, all human breast cancer lines induiced up-regulation of EPC populations. In particular, WIBC-9 demonstrated the highest level of induction among the lines. rhGM-CSF (50 ng_4 i.p.) and rhVEGF (I0 ng_4 i.p.) mobilisation induced up-regulation of EPC populations at the same level as WIBC-9. $* P<0.05, * * P<0.01$ compared with control. 

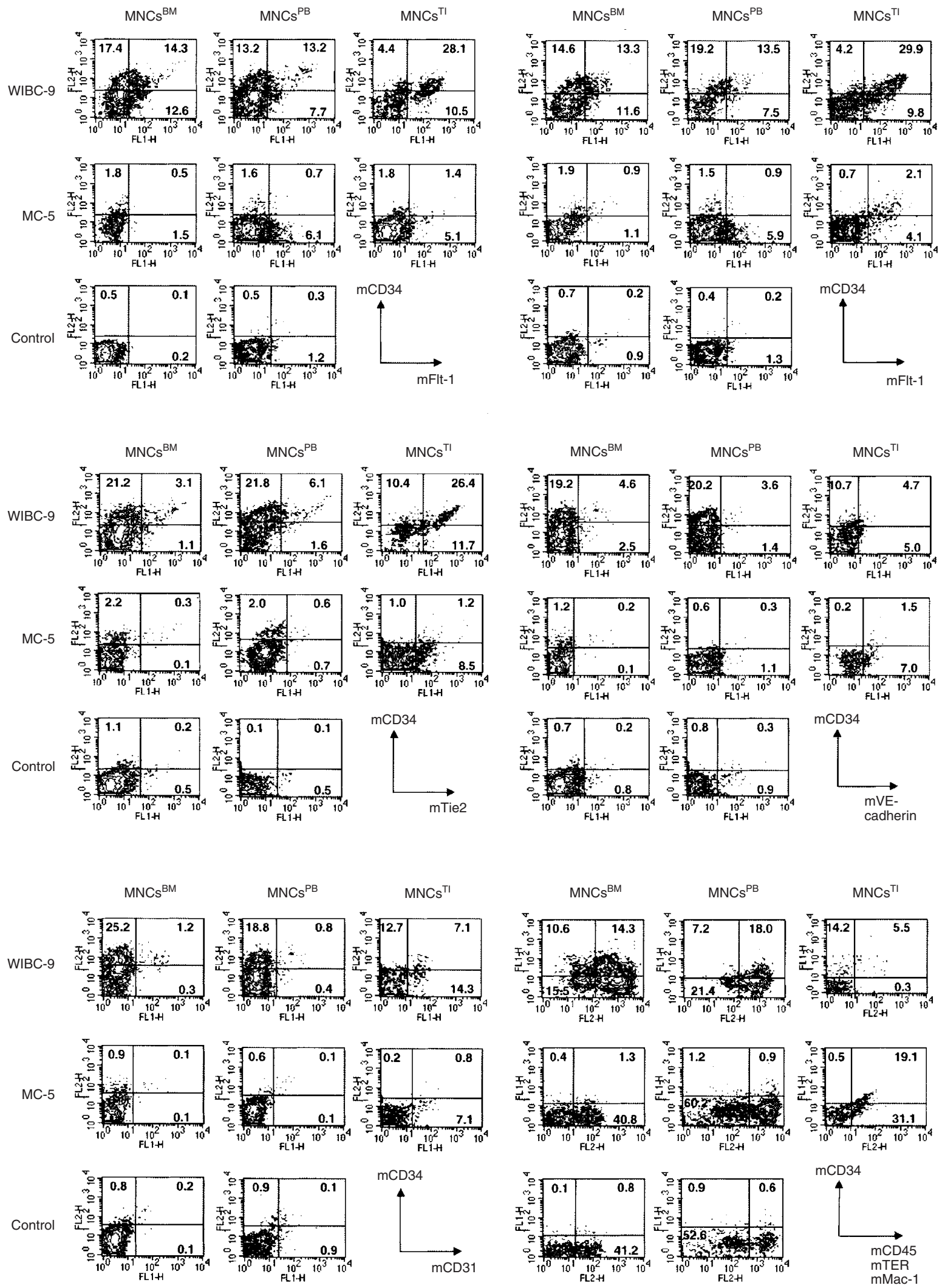

Figure I Flow cytometry (quantitation of EPCs and ECs). In WIBC-9 xenografted mice, the populations of EPCs were markedly elevated in MNCs de-

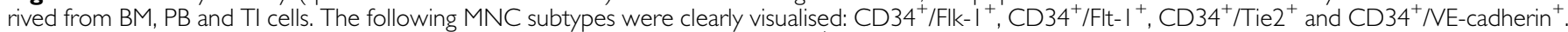
In WIBC-9 mice, the population of cells that were CD45-/TER-/Mac- ${ }^{-} / \mathrm{CD} 34^{+}$was approximately $10 \%$, almost equal to the population of cells that were $\mathrm{CD} 34^{+} / \mathrm{Flk}-\mathrm{I}^{+} \mathrm{MNCs}$. The EC population (CD34 $/ \mathrm{CD}-3 \mathrm{I}^{+} \mathrm{MNCs}$ ) was also high in WIBC-9 mice, although not as high as the EPC population. EC populations of MC-5 xenografted mice were higher than those of the controls. 
examined. On day 13, numbers of AT cells in each BM and $\mathrm{PB}$ sample were counted.

\section{Immunocytochemistry}

Spindle-shaped AT cells observed at 14 days of culture were subjected to immunocytochemistry to analyse the expression of Mac-1-FITC (Pharmingen).

\section{Cellular uptake of acetylated LDL}

We investigated Ac-LDL uptake (a process characteristic of endothelial lineage) into AT cells (Asahara et al, 1997). AT cells cultured on fibronectin were incubated in medium containing $10 \mu \mathrm{g} \mathrm{ml}^{-1}$ DiI-labelled Ac-LDL (DiI-Ac-LDL; Molecular Probes, Eugene, OR, USA) for $24 \mathrm{~h}$ at $37^{\circ} \mathrm{C}$. Cells were then examined under a fluorescence microscope.

\section{Culture of EC and EPC on HUVEC monolayer}

BM-derived MNCs from WIBC-9 xenografted mice that are mCD $34^{+}$and $\mathrm{mFlt}^{+}{ }^{+}$(sorted by FACS), were cultured in Stem pro (GIBCO BRL, Grand Island, NY, USA) for 13 days and incubated in the medium containing $10 \mu \mathrm{g} \mathrm{ml}^{-1}$ DiI-labelled Ac-LDL (DiI-Ac-LDL; Molecular Probes, Eugene, OR, USA) for $24 \mathrm{~h}$ at $37^{\circ} \mathrm{C}$. These cells were seeded on HUVEC monolayer cultured on Growth Factor Reduced Matrigel matrix (Becton Dickinson Labware, Bedford, MA) on day 5.

\section{Preparation of $\mathrm{BM}$ derived $\mathrm{CD} 34^{+}+\mathrm{Flk}-1^{+}$subset and} $\mathrm{CD}^{+} 4^{+}+\mathrm{Flk}_{-1}{ }^{-}$subset cultured conditioned medium and determination of mVEGF and mIL-8 concentration by ELISA

$\mathrm{BM}$ derived $\mathrm{CD} 34^{+}+\mathrm{Flk} 1^{+} \mathrm{MNC}$ subset and $\mathrm{CD} 34^{+}+\mathrm{Flk}-1^{-} \mathrm{MNC}$ subset $\left(1 \times 10^{5}\right.$ cells well $\left.^{-1}\right)$ were sorted by using FACS $(n=5)$ and incubated for 14 days at $37^{\circ} \mathrm{C}$, and the supernatants were collected every $12 \mathrm{~h}$ and stored at $-80^{\circ} \mathrm{C}$ until used. Concentrations of mVEGF and mIL- 8 were measured by ELISA in $100 \mu$ l samples of supernatant, using Immunoassay Kits (Immuno-Biological Laboratories Co. Ltd., Fujioka, Japan). Each assay was performed in triplicate.

\section{Statistical analysis}

All data are expressed as the mean \pm s.d. StatView computer software (ATMS Co., Tokyo, Japan) was used for the statistical analysis of differences in results of MTT, migration assay and EPC population between groups. Two-sided $P<0.05$ and $P<0.01$ were considered to indicate statistical significance.

\section{RESULTS}

\section{Flow cytometry (quantitation of EPCs) (Table 1 and} Figures 1 and 2)

The population of EPCs was markedly elevated in all three sources of MNCs (BM, PB and TI) in WIBC-9 xenografted mice. The MNC subtypes that were clearly visualised were CD34-positive $\left(\mathrm{CD} 34^{+}\right) / \mathrm{Flk}^{+} 1^{+}, \mathrm{CD} 34^{+} / \mathrm{Flt} 1^{+}, \mathrm{CD} 34^{+} / \mathrm{Tie}^{+}$and $\mathrm{CD}^{+} 4^{+} / \mathrm{VE}$-cadherin ${ }^{+}$. It should be noted that, in WIBC-9 mice, the population of cells that were CD45-negative $\left(\mathrm{CD} 45^{-}\right) /$ TER $119^{-} / \mathrm{Mac}^{-}{ }^{-} / \mathrm{CD} 34^{+}$(considered part of the EPC population) was around $10 \%$, which is almost equal to the number of $\mathrm{CD} 34^{+} / \mathrm{Flk}^{+} 1^{+} \mathrm{MNCs}$ in $\mathrm{BM}$ and $\mathrm{PB}$. The EC population $\left(\mathrm{CD} 34^{+} / \mathrm{CD} 1^{+} \mathrm{MNCs}\right)$ was also prominent in WIBC-9 mice. The real number of MNCs in $\mathrm{PB}$ was also elevated in WIBC9, MCF-7/hVEGF, and rhGM-CSF mice. EPC and EC populations were slightly elevated in $\mathrm{MC}-5$. These results are shown in Table 1, with additional data for MC-2, MC-18, MCF-7 and MCF-7/hVEGF, plus data for chemotactic effects. All human breast cancer lines induced EPC populations in BM, PB
BM derived MNCs
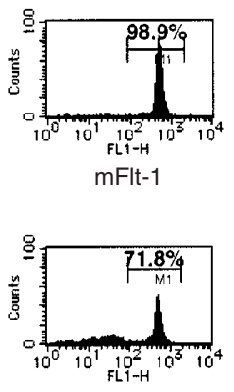

mTie-2
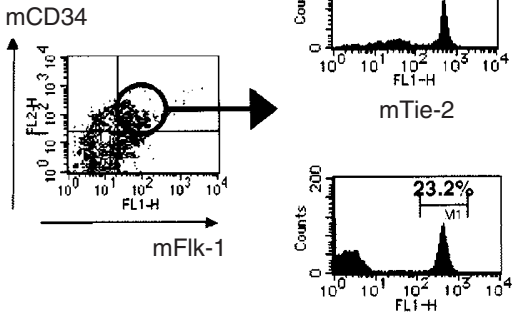

mVE-

cadherin

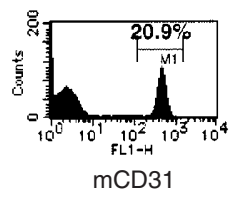

PB derived MNCs
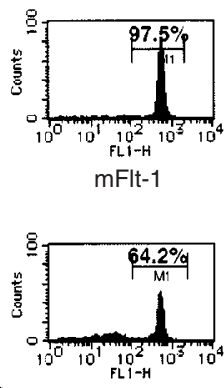

$\mathrm{mTie}-2$

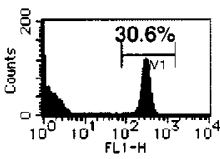

mVE-

cadherin

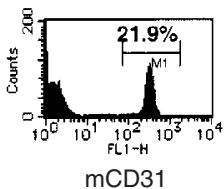

TI derived MNCs

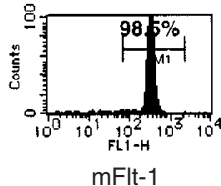

$\mathrm{mFlt}-1$
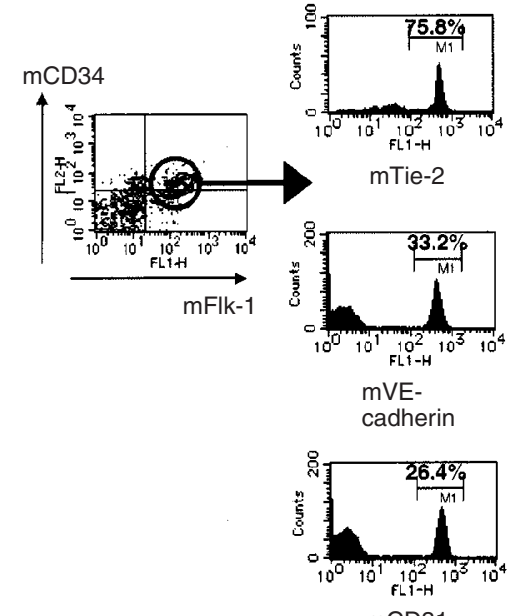

mCD31

Figure 2 EPCs(mCD34+, mFlk-I+) in the bone marrow and peripheral blood in WIBC-9, included a large number of FLTI+(98.9\%/97.5\%), and TIE2+(7I.8\%/64.2\%) but include small number of VE-cadherin (23.2\%/30.6\%) and CD $31+(20.9 \% / 20.9 \%)$. 
compared with control. WIBC-9 induced the highest EPC populations $(10 \%$ or greater) among the breast cancer lines. rhGMCSF $(50 \mathrm{ng} \times 4$, i.p.) and rhVEGF $(10 \mathrm{ng} \times 4$, i.p.) also induced significantly higher levels of EPC populations only in peripheral blood compared with control. EPCs(mCD34+, mFlk-1+) in the $\mathrm{BM}, \mathrm{PB}$ and $\mathrm{TI}$ enumerated by three-color flow cytometry

\section{A}

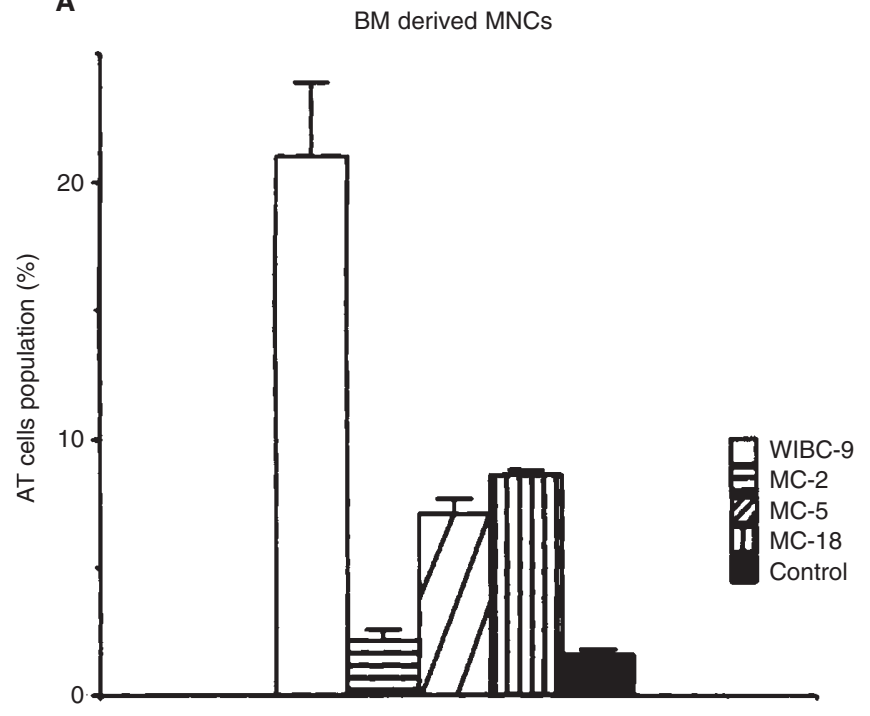

B

Control

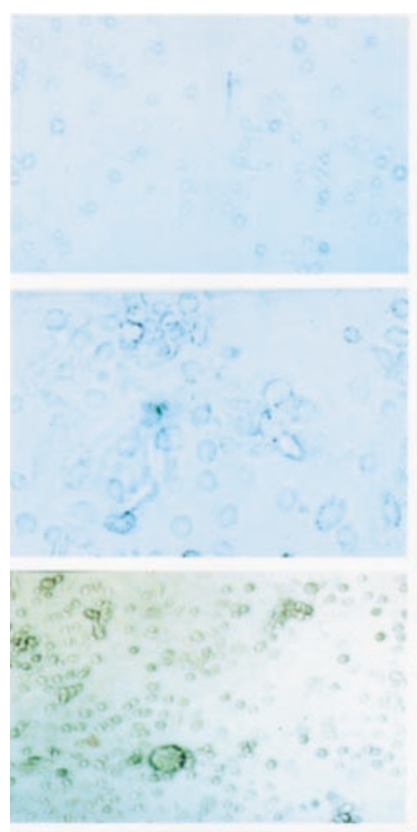

WIBC-9
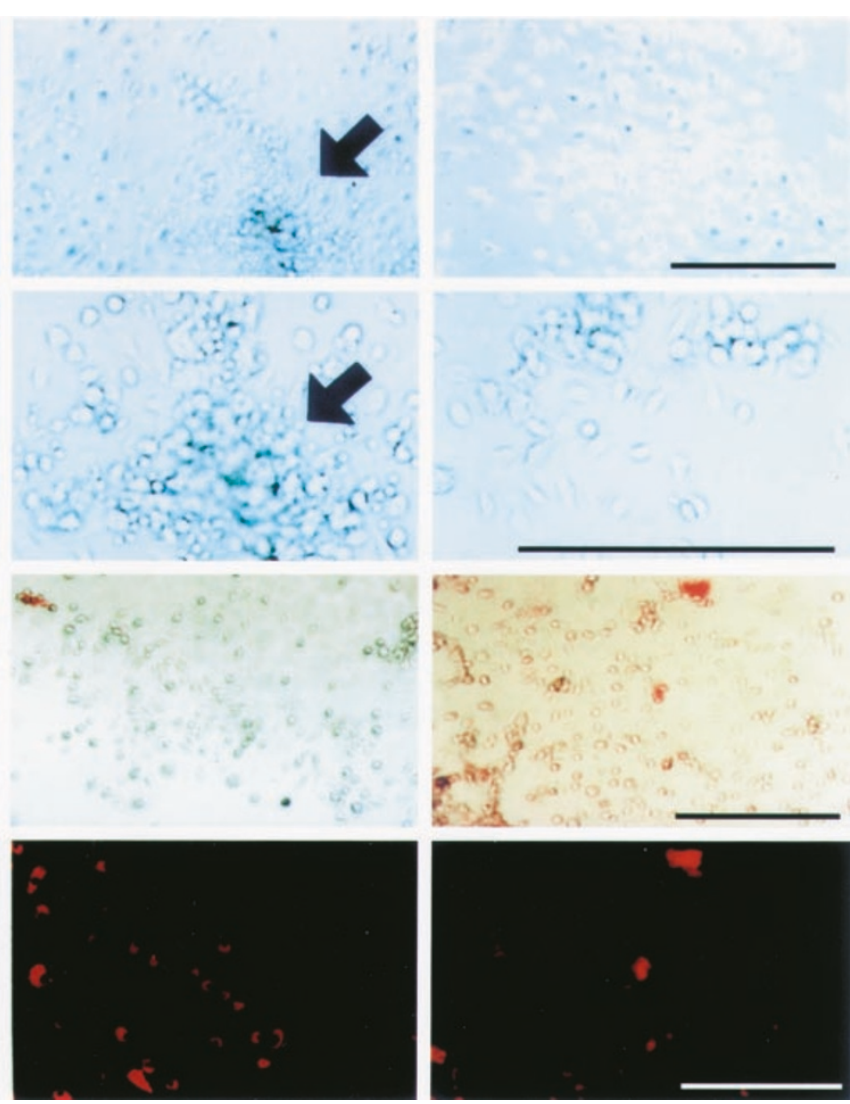

Figure 3 (A) AT cell population in the xenografts. AT cells, including ECs were counted. In WIBC-9 samples, the AT cell population was high. AT populations in other cancer lines were higher than in the control, a finding consistent with the size of the CD34 $/$ /Flk- ${ }^{+}$MNC population. (B) BM-derived EPC morphogenesis on murine fibronectin. On day 4 after plating CD34 $4^{+}$floating MNCs, spindle-shaped AT cells and cluster formation were evident in WIBC-9 samples. On day 13, all AT cells were found to uptake Dil-labelled acLDL. Immunocytochemistry revealed that all cells were Mac-I - negative. Each scale bar is $50 \mu \mathrm{m}$. 
showed high expression of mFlt-1 and low expression of mCD31.

\section{AT cell population in samples from xenografted mice (Figure 3A)}

In WIBC-9 samples, AT cells comprised markedly high percentages of total cells $(20 \%$ or greater). In other lines, AT cell populations were higher than that of the control, a finding consistent with the observed $\mathrm{CD} 34^{+} / \mathrm{Flk}-1^{+}$populations.

\section{BM-derived EPC morphogenesis on murine fibronectin (Figure 3B)}

On day 4 after plating the $\mathrm{CD} 34^{+}$floating MNCs, spindle-shaped AT cells and cluster formation were clearly visible in WIBC-9 samples. On day 13, WIBC-9 AT cells were found to uptake DiIlabelled acLDL. Immunocytochemistry revealed that these cells were negative for Mac-1, indicating that they were not of a monocyte lineage.

\section{Culture of EC and EPC on HUVEC monolayer (Figure 4)}

BM-derived MNCs that are $\mathrm{mCD} 34^{+}$and $\mathrm{mFlt}-1^{+}$incorporated DiI-labelled acLDL and were integrated in a HUVEC monolayer (forming capillary networks) implying their maturation to ECs.

\section{The production of angiogenic factors by putative EPCs (Figure 5)}

$\mathrm{BM}$ derived $\mathrm{CD} 34^{+} \mathrm{Flk}-1^{+}$MNC subset and $\mathrm{CD} 34^{+} \mathrm{Flk}-1^{-} \mathrm{MNC}$ subset produced mVEGF and mIL-8 on time course. The former subset demonstrated significantly higher levels of murine VEGF and IL- 8 in culture supernatant on time course by ELISA.

\section{DISCUSSION}

Neovascularisation encompasses both angiogenesis and vasculogenesis. In angiogenesis (the classic paradigm for new vessel growth), mature, differentiated ECs break free from their basement membrane, migrate and proliferate to form branches of parental vessels. The fact that tumours induce angiogenesis indicates that tumour development and metastasis are dependent upon neovascularisation, and suggests that this relationship involves angiogenic growth factors that are specific to neoplasms (Folkman and Klagsbrun, 1987; Kendall and Thomas, 1993; O'Reilly et al, 1997; Goldman et al, 1998; Tanaka et al, 1998; Ferrara and Alitalo,
1999; Mori et al, 2000). Although the therapeutic potential of anti-angiogenic factors is reportedly promising, their antiangiogenic mechanisms (inhibition of migration, proliferation and tube formation) have not been well characterised. Vasculogenesis involves participation of BM-derived EPCs that circulate to sites of neovascularisation, where they differentiate into mature ECs (Asahara et al, 1997, 1999; Isner and Asahara, 1999; Takahashi et al, 1999; Kalka et al, 2000; Murohara et al, 2000). The results of the present study indicate that six human breast cancer lines, including the IBC line WIBC-9, induce postnatal EPC kinetics as well as EC kinetics. The chemotactic modulation of proliferation and migration of EPCs that we observed was mainly the result of VEGF mobilisation, a finding consistent with those of a previous study (Asahara et al, 1997). MCF-7/hVEGF and WIBC-9 showed markedly enhanced growth on mice and higher microvascular density by histology compared with MCF-7 in this series study (Shirakawa et al, 2001) as previously described (Lewin et al, 1999). This enhanced growth may be a result of contribution of endothelial precursors induced by angiogenic factor such as VEGF (de Bont et al, 2001). Moreover, MNCs which contain haematopoietic precursors as well as EPCs in peripheral blood markedly increased in WIBC-9 and MCF7/hVEGF xenografted mice. This may be due to the mobilisation of the common precursors for EPCs and haematopoietic cells residing in bone marrow led by the elevation of plasma levels of factors such as VEGF secreted by cancer cells (Hattori et al, 2001). Thus, our results support the notion that $\mathrm{BM}$-derived precursors provide a sufficient source of ECs to enhance the growth of breast cancer in vivo. In vitro, the $\mathrm{CD}^{+} 4^{+}$floating MNCs on day 4 after plating, spindle-shaped AT cells and cluster formation were clearly visible in WIBC- 9 samples. Although, we have already reported the TI EPCs in WIBC-9 xenografted mice(Shirakawa et al, 2002), the population of EPCs was markedly elevated in all three sources of MNCs (BM, PB and TI) in WIBC-9 among the xenografted mice. These facts possibly show the induction of vasculogenesis especially in WIBC-9. On day 13, AT cells from WIBC-9 were found to uptake DiI-labelled acLDL. Immunocytochemistry revealed that these cells were negative for Mac-1, indicating that they were not of a monocyte lineage. These facts possibly show the maturation from EPC to EC in vitro culture.

In WIBC-9, human angiogenic factors (hAngl, hVEGF, hbFGF) and murine angiogenic factors (mflt- $1, \mathrm{~m}$ integrin $\beta 3$, mVEGF, and $\mathrm{mCD} 31$ ), were expressed at higher levels than they were in the three non-IBC xenografts. However, because our results indicate that the human breast cancer lines MC-2, MC-5 and MC-18 secrete low levels of hVEGF, modulation by accessory molecules constitutes a cytokine network, and autocrine or paracrine secre-
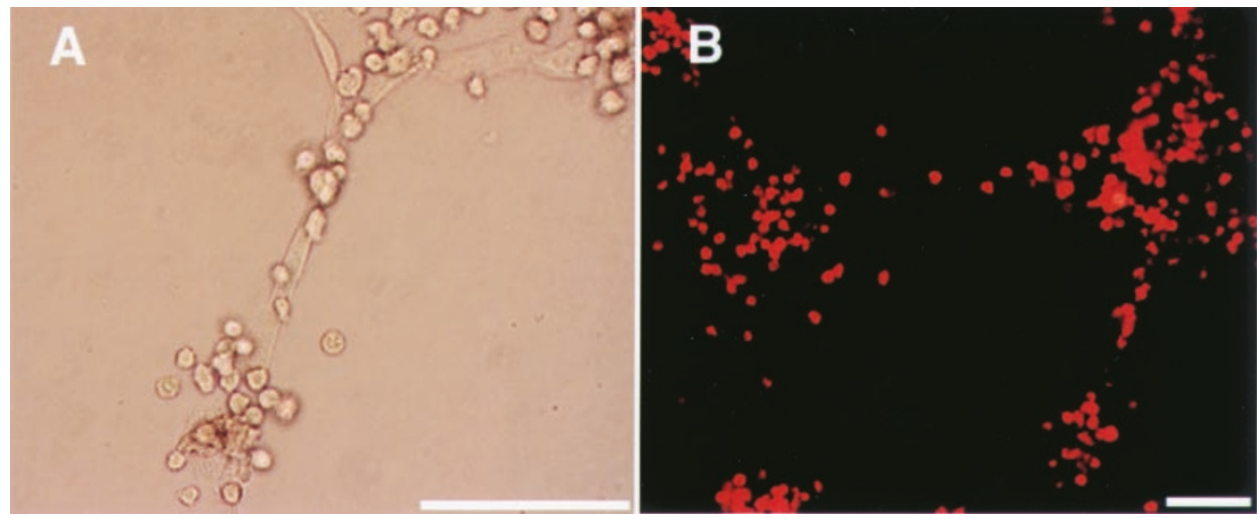

Figure 4 (A) HUVECs and BM-derived EPCs (mCD34 ${ }^{+}$and $\mathrm{mFlt}-\mathrm{I}^{+}$) formed capillary networks. (B) BM-derived EPCs, which incorporated Dil-labelled acLDL, were integrated with HUVECs. Phase contrast photomicrographs showed capillary networks. Each scale bar is $10 \mu \mathrm{m}$. 
tion of angiogenic factors is likely to be associated with modulation of EPC recruitment (Shirakawa et al, 2001). The VEGF family receptor, $m f l t-1$ and the Ang receptor, $h$ Tie-1, and $h$ Tie-2, mtie-2 was expressed at a higher level in WIBC-9, but $m f l k-1$ and $m f l t-4$
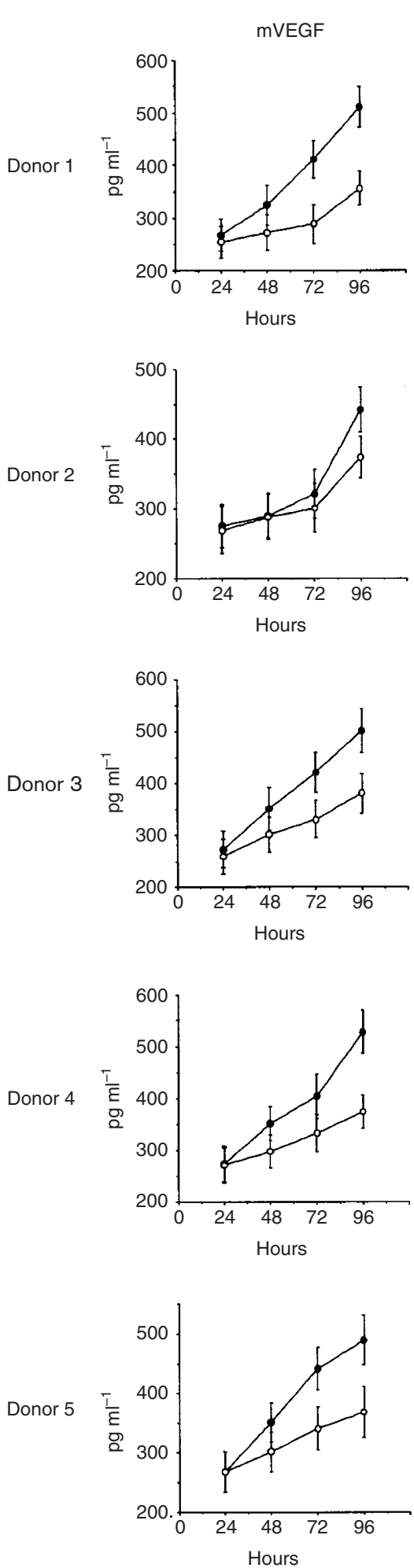
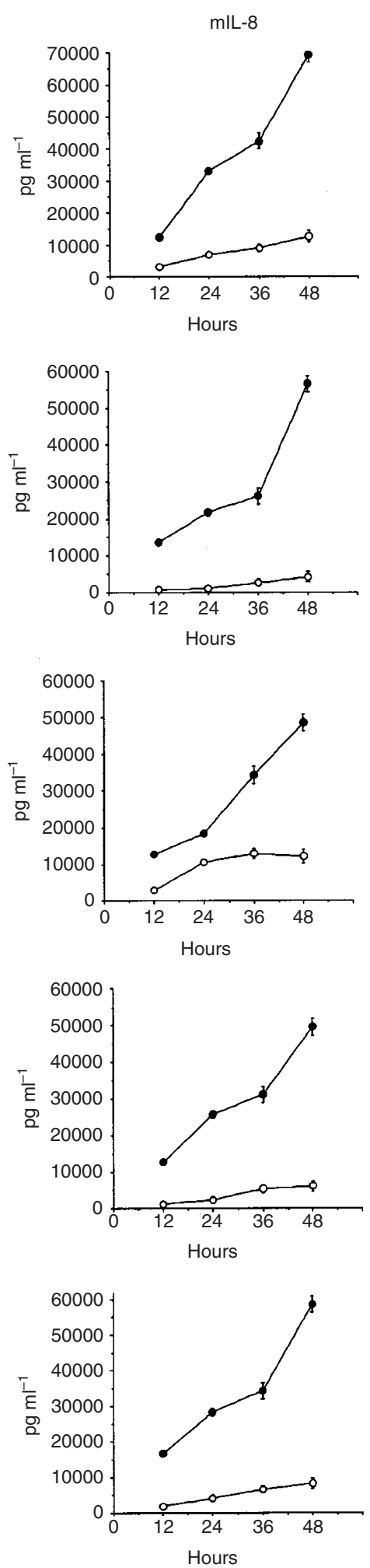

Figure $5 \mathrm{BM}$ derived $\mathrm{CD} 34^{+}+\mathrm{Flk}-\mathrm{I}^{+} \mathrm{MNC}$ subset and $\mathrm{CD} 34^{+}+\mathrm{Flk}-\mathrm{I}^{-} \mathrm{MNC}$ subset $\left(\mathrm{I} \times 10^{5}\right.$ cells well $\left.^{-1}\right)$ were sorted by using FACS $(n=5)$ and incubated for 14 days at $37^{\circ} \mathrm{C}$, and the supernatants were collected every $12 \mathrm{~h}$ and stored at $-80^{\circ} \mathrm{C}$ until used. Concentrations of mVEGF and mlL-8 were measured by ELISA in $100 \mu \mathrm{l}$ samples of supernatant, using Immunoassay Kits (Immuno-Biological Laboratories Co., Ltd., Fujioka, Japan). Each assay was performed in triplicate. 
were not detected in WIBC-9. Expression of $h F l t-1$ and KDR was detected in all xenografts. The cytokine, $h I L-1 \beta$ was only detected in WIBC-9, and a higher expression of $h I L-8$ was detected in WIBC-9. The adhesion molecule, $h$ integrin $\beta 3, m$ integrin $\beta 3$ and $m$ integrin $\alpha v$ were detected at higher levels in WIBC-9 as previously described (Shirakawa et al, 2001).

BM-, PB- and TI-derived murine EPCs and ECs from human breast cancer-bearing mice were found to exhibit a specific pattern of cell surface antigen expression; i.e., double positive for mCD34 and mFlk-1. The subtypes, which may show the maturation of EPC, detected were $\mathrm{mCD} 34^{+} / \mathrm{mFlk} 1^{+}, \mathrm{mCD} 34^{+} / \mathrm{mFlt}-1^{+}$, $\mathrm{mCD} 34^{+} / \mathrm{mTie}^{+} 2^{+}, \quad \mathrm{mCD} 34^{+} / \mathrm{mVE}^{-c_{2}} \mathrm{mherin}^{+}$and $\mathrm{mCD} 34^{+} /$ mCD $31^{+}$. In this model, we detected both EPCs and ECs, or their subtypes (maturation), among BM-, PB- and TI-derived cells. The data of multiple markers analysis, which are Flk-1, Flt-1, Tie-2, VEcadherin, and CD31 by using tri-color FACS, indicated that the populations of $\mathrm{CD} 34^{+}+\mathrm{FLK}^{+}$in the bone marrow and peripheral blood in WIBC-9, included a large number of FLT1+(98.9\%/ $97.5 \%)$, and TIE2+(71.8\%/64.2\%) but include small number of VE-cadherin $(23.2 \% / 30.6 \%)$ and $\mathrm{CD} 31+(20.9 \% / 20.9 \%)$. Induced EPCs and ECs were clearly shown to be non-malignant cells, and May-Gimsa staining revealed that they were of the same phenotype as rhVEGF- and rhGM-CSF-mobilised EPCs and ECs (data not shown). Surprisingly, induced EPC populations which were positive of mCD34 and mFlk-1, showed the production of mVEGF and mIL- 8 in culture supernatant on time course. This result

\section{REFERENCES}

Asahara T, Takahashi T, Masuda H, Kalka C, Chen D, Iwaguro H, Inai Y, Silver M, Isner JM (1999) VEGF contributes to postnatal neovascularization by mobilizing bone marrow-derived endothelial progenitor cells. EMBO 18: $3964-3972$

Asahara T, Murohara T, Sullivan A, Silver M, van der Zee R, Li T, Witzenbichler B, Schatteman G, Isner JM (1997) Isolation of putative progenitor endothelial cells for angiogenesis. Science 275: 964-967

de Bont ES, Guikema JE, Scherpen F, Meeuwsen T, Kamps WA, Vellenga E, Bos NA (2001) Mobilized human CD34+ hematopoietic stem cells enhance tumor growth in a nonobese diabetic/severe combined immunodeficient mouse model of human non-Hodgkin's lymphoma. Cancer Res 61: $7654-7659$

Ferrara N, Alitalo K (1999) Clinical applications of angiogenic growth factors and their inhibitors. Nature Med 5: 1359-1364

Folkman J, Klagsbrun M (1987) Angiogenic factors. Science 235: 442-447

Gerber HP, Malik AK, Solar GP, Sherman D, Liang XH, Meng G, Hong K, Marsters JC, Ferrara N (2002) VEGF regulates haematopoietic stem cell survival by an internal autocrine loop mechanism. Nature 417: 954-958

Goldman CK, Kendall RL, Cabrera G, Soroceanu L, Heike Y, Gillespie GY, Siegal GP, Mao X, Bett Aj, Huckle WR, Thomas KA, Curiel DT (1998) Paracrine expression of a native soluble vascular endothelial growth factor receptor inhibits tumor growth, metastasis, and mortality rate. Proc Natl Acad Sci USA 95: 8795-8800

Hattori K, Dias S, Heissig B, Hackett NR, Lyden D, Tateno M, Hicklin DJ, Zhu Z, Witte L, Crystal RG, Moore MA, Rafii S (2001) Vascular endothelial growth factor and angiopoietin-1 stimulate postnatal hematopoiesis by recruitment of vasculogenic and hematopoietic stem cells. J Exp Med 193: $1005-1014$

Holash J, Maisonpierre PC, Compton D, Boland P, Alexander CR, Zagzag D, Yancopoulos GD, Wiegand SJ (1999) Vessel cooption, regression, and growth in tumors mediated by angiopoietins and VEGF. Science 284: $1994-1998$

Isner JM, Asahara T (1999) Angiogenesis and vasculogenesis as therapeutic strategies for postnatal neovascularization. J Clin Invest 103: 1231-1236

Kalka C, Masuda H, Takahashi T, Kalka-Moll WM, Silver M, Kearney M, Li $\mathrm{T}$, Isner JM, Asahara T (2000) Transplantation of ex vivo expanded endothelial progenitor cells for therapeutic neovascularization. Proc Natl Acad Sci USA 97: 3422 - 3427 implies autocrine regulation of proliferation of these precursors in vivo, and coincides with the recent report of the regulation of haematopoietic stem cells (Gerber et al, 2002). In our model, this autocrine cascade may play an important role of the induction of vasculogenesis and the tumour growth.

The chemotactic expansion of EPCs derived from PB or cord blood and transplantation of these EPCs have previously been reported (Asahara et al, 1997, 1999; Isner and Asahara, 1999; Takahashi et al, 1999; Kalka et al, 2000; Murohara et al, 2000); transplanted EPCs were found to significantly proliferate in ischaemic foci and differentiate in situ through a process of vasculogenesis. In the present study, we demonstrated that breast cancer-bearing mice exhibit significant expansion of precursors including EPCs and ECs; specifically, maturation and proliferation of these cells in tumours was clearly evident.

\section{ACKNOWLEDGEMENTS}

We wish to thank Minako Takahashi and Takayuki Morikawa for their excellent technical assistance. This study was supported by a Grant-in-Aid for Cancer Research for the Second Term Comprehensive 10-Year Strategy for Cancer, from the Ministry of Health, Labour and Welfare, Japan.
Kendall RL, Thomas KA (1993) Inhibition of vascular endothelial cell growth factor activity by an endogenously encoded soluble receptor. Proc Natl Acad Sci USA 90: 10705-10709

Lewin M, Bredow S, Sergeyev N, Marecos E, Bogdanov Jr A, Weissleder R (1999) In vivo assessment of vascular endothelial growth factor-induced angiogenesis. Int J Cancer 83: 798-802

Mori A, Arii S, Furutani M, Mizumoto M, Uchida S, Furuyama H, Kondo Y, Gorrin-Rivas MJ, Furumoto K, Kaneda Y, Imamura M (2000) Soluble Flt1 gene therapy for peritoneal metastases using HVJ-cationic liposomes. Gene Ther 7: 1027-1033Murohara T, Ikeda H, Duan J, Shintani S, Sasaki $\mathrm{K}$, Eguchi $\mathrm{H}$ et al (2000) Transplanted cord blood-derived endothelial precursor cells augment postnatal neovascularization. J Clin Invest 105: $1527-1536$

O’Reilly MS, Boehm T, Shing Y, Fukai N, Vasios G, Lane WS et al (1997) Endostatin: an endogenous inhibitor of angiogenesis and tumor growth. Cell 88: $277-285$

Shirakawa K, Tsuda H, Heike Y, Kato K, Inomata M, Sasaki H, Kasumi F, Yoshimoto M, Iwanaga T, Konishi F, Terada M, Wakasugi H (2001) Absence of endothelial cells, central necrosis, and fibrosis are associated with aggressive inflammatory breast cancer. Cancer Res 61: 445-451

Shirakawa K, Shibuya M, Heike Y, Tsuda H, Takashima S, Watanabe I, Konishi F, Kasumi F, Goldman CK, Thomas KA, Bett A, Terada M, Wakasugi H (2002) Tumor-infiltrating endothelial cells and endothelial precursor cells in inflammatory breast cancer. Int J Cancer 99: 344-351

Takahashi T, Kalka C, Masuda H, Chen D, Silver M, Kearney M, Magner M, Ishner JM (1999) Ischemia- and cytokine-induced mobilization of bone marrow-derived endothelial progenitor cells for neovascularization. Nat Med 5: $434-438$

Tanaka T, Cao Y, Folkman J, Fine HA (1998) Viral vector-targeted antiangiogenic gene therapy utilizing an angiostatin complementary DNA. Cancer Res 58: $3362-3369$

Workman P, Twentyman P, Balkwill F, Balman A, Chaplin D, Double J, Embleton J, Newell D, Raymond R, Stables J, Stephans T, Wallace J (1998) United Kingdom Co-ordinating Committee on Cancer Research (UKCCCR) Guidelines for the Welfare of Animals in Experimental Neoplasia (Second Edition). Br J Cancer 77: 1-10 